\title{
Iridium(III) and Rhodium(III) compounds of dipyridyl-N-alkylimine and dipyridyl-NH-ketimine: Spectral characterization and crystal structure
}

\author{
KEISHAM S SINGH ${ }^{\mathrm{a}, *}$, PENG WANG ${ }^{\mathrm{b}}, \mathrm{NITEEN} \mathrm{A} \mathrm{NARKHEDE}^{\mathrm{c}}$ \\ and YURIJ MOZHARIVSKYJ ${ }^{\mathrm{b}}$ \\ ${ }^{a}$ Bioorganic Chemistry Laboratory, CSIR-National Institute of Oceanography, Goa 403 004, India \\ ${ }^{b}$ Department of Chemistry, McMaster University, West Hamilton, Ontario, L8S 4M1, Canada \\ ${ }^{\mathrm{c} C S I R-I n d i a n ~ I n s t i t u t e ~ o f ~ I n t e g r a t i v e ~ M e d i c i n e, ~ M u m b a i ~} 400$ 053, India \\ Email: keisham@nio.org; keisham.sarjit@gmail.com
}

MS received 27 October 2016; revised 3 January 2017; accepted 14 January 2017

\begin{abstract}
Pentamethylcyclopentadienyl iridium(III) and rhodium(III) complexes of formulation [( $\eta^{5}-$ $\left.\left.\left.\mathrm{C}_{5} \mathrm{Me}_{5}\right) \mathrm{M}\left\{\left(\mathrm{C}_{5} \mathrm{H}_{4} \mathrm{~N}\right)_{2} \mathrm{C}=\mathrm{NR}\right)\right\} \mathrm{Cl}\right] \mathrm{PF}_{6}$ were prepared by the reaction of $\left[\mathrm{MCl}_{2}\left(\eta^{5}-\mathrm{C}_{5} \mathrm{Me}_{5}\right)\right]_{2}(\mathrm{M}=\mathrm{Ir}$ or $\mathrm{Rh})$ with dipyridyl-N-alkylimine ligands, $\left(\mathrm{C}_{5} \mathrm{H}_{4} \mathrm{~N}\right)_{2} \mathrm{C}=\mathrm{NR}(\mathrm{R}=\mathrm{Me}$ or Et $)$ in the presence of $\mathrm{NH}_{4} \mathrm{PF}_{6}$ at $\mathrm{room}$ temperature. The reaction also produced an unexpected dipyridyl-NH-ketimine organometallic compound $\left[\left(\eta^{5}-\mathrm{C}_{5} \mathrm{Me}_{5}\right) \mathrm{M}\left\{\left(\mathrm{C}_{5} \mathrm{H}_{4} \mathrm{~N}\right)_{2} \mathrm{C}=\mathrm{NH}\right\} \mathrm{Cl}\right] \mathrm{PF}_{6}$ as minor product when the reaction was performed under refluxing acetonitrile. The $\mathrm{NH}$-ketimine compounds were formed via $\mathrm{N}-\mathrm{C}$ single bond cleavage of imine ligand resulting in coordination of the transformed ligand, $\left(\mathrm{C}_{5} \mathrm{H}_{4} \mathrm{~N}\right)_{2} \mathrm{C}=\mathrm{NH}$ to the metal centre. Complexes were obtained as their hexafluorophosphate salts and characterized based on IR, NMR and ESI-MS spectroscopic data. Authenticity of NH-ketimine organometallic compound was established by single crystal X-ray analysis of a representative compound, which crystallized in orthorhombic space group Pbcn and has a pseudo-octahedral geometry around the metal ion.
\end{abstract}

Keywords. Dipyridyl-NH-ketimine; Iridium; Rhodium; N-C bond cleavage; spectroscopy; crystal structure.

\section{Introduction}

Current interest on the synthesis of iridium(III) and rhodium(III) complexes bearing $\eta^{5}-\mathrm{C}_{5} \mathrm{Me}_{5}$ fragment is due to their application in biology ${ }^{1-3}$ and catalysis., ${ }^{4,5}$ Indeed, several iridium(III) and rhodium(III) complexes have been used as catalysts for a wide range of reactions such as in hydrogenation, ${ }^{6}$ hydrosilytion, ${ }^{7}$ amination, ${ }^{8} \mathrm{C}-\mathrm{C}$ coupling ${ }^{9,10}$ and Diels-Alder reactions. ${ }^{11}$ Furthermore, compounds of this classes exhibited anticancer ${ }^{12-14}$ and DNA intercalative properties. ${ }^{15,16}$ Owing to their wide applications, synthesis of iridium(III) and rhodium(III) complexes bearing $\eta^{5}-\mathrm{C}_{5} \mathrm{Me}_{5}$ fragment have been a subject of interest over the past years. ${ }^{16-19}$ Numerous studies have been reported for their synthesis of which complexes with $\mathrm{N}, \mathrm{N}$-donor imine ligands were the most prominent. Specifically, imine ligands containing pyridyl groups have been extensively studied, ${ }^{20}$ because of the possibility to construct diverse ligands and easy accessibility through a simple step by condensation of amine with aldehydes or ketones.

It is noteworthy that transition metals can mediate cleavage of either $\mathrm{C}=\mathrm{N}^{21,22}$ or $\mathrm{N}-\mathrm{C}$ bond. ${ }^{23-26}$

*For correspondence
Recently, Prasad et al., reported hydrolysis of $\mathrm{C}=\mathrm{N}$ bond of an imine ligand derived from acetylthiazole in $\mathrm{Rh}(\mathrm{III})$ complex. ${ }^{22}$ Whereas, Geng et al. ${ }^{21}$ reported $\mathrm{C}=\mathrm{N}$ bond cleavage and partial hydrolysis of Schiff's base for a ruthenium(II) complex. ${ }^{21}$ A less common bond cleavage involving $\mathrm{N}-\mathrm{C}$ single bond were reported with $\mathrm{Pd}^{23}$ and $\mathrm{Ru} .{ }^{24-26}$ Albert et al., have reported $\mathrm{N}-\mathrm{C}$ bond cleavage for amino acid fragment of a coordinated imine from a palladium complex resulting in the formation of $\mathrm{NH}$-aldimine compound. ${ }^{23}$ Previously, ruthenium mediated selective cleavage of $\mathrm{N}-\mathrm{C}$ bond of a diimine functional ligand was reported by Lahiri's group. ${ }^{24}$ They also described cleavage of N-N or N-C bond of dinuclear bridging imine ligand by the reaction of imine ligand with $\left[\mathrm{Ru}(\mathrm{bpy})_{2}(\mathrm{EtOH})_{2}\right]^{2+} .{ }^{25,26}$ However, as far as our knowledge goes, such N-C bond cleavage in iridium(III) and rhodium(III) complexes were previously not known. As a part of our study on dipyridyl-N-alkyimine complexes,${ }^{27}$ herein we report the synthesis of iridium(III) and rhodium(III) complexes containing dipyridyl-N-alkyl imine ligands [1] $\mathbf{P F}_{6}-[4] \mathbf{P F}_{6}$. In addition, we report an unexpected formation of iridium(III) and rhodium(III)-NH-ketimine organometallic compounds ([5] $\mathbf{P F}_{6}$ and $\left.[\mathbf{6}] \mathbf{P F}_{6}\right)$. Spectroscopic characterization of [1] $\mathbf{P F}_{6}-[\mathbf{6}] \mathbf{P F}_{6}$ and molecular 
structure of one NH-ketimine compound $\left([\mathbf{6}] \mathbf{P F}_{\mathbf{6}}\right)$ is described.

\section{Experimental}

\subsection{General experimental procedures}

All solvents were analytical grade and used as received. $\mathrm{IrCl}_{3} .3 \mathrm{H}_{2} \mathrm{O}$ and $\mathrm{RhCl}_{3} \cdot 3 \mathrm{H}_{2} \mathrm{O}$ were purchased from Arora Matthey Ltd., India. Methyl amine, ethyl amine (2.0 M solution) and dipyridylketone were obtained from Sigma Aldrich Pvt. Ltd. Infrared spectra were obtained in a diffuse reflection spectroscopy (DRS) assembly on a Shimzadzu PC-1380 spectrometer with sample prepared in $\mathrm{KBr}$ disk. NMR spectra were recorded on a Bruker Avance $300 \mathrm{MHz}$ spectrometer at $300.13\left({ }^{1} \mathrm{H}\right), 75.47\left({ }^{13} \mathrm{C}\right) \mathrm{MHz}$ with $\mathrm{SiMe}_{4}$ as internal reference and coupling constants are given in Hertz. Mass spectral data were obtained on a QSTAR-TOF MS/MS of Applied Biosystems or Waters UPLC-MSMS (Xevo TQD) mass spectrometers. The precursor compounds $\left[\left\{\left(\eta^{5}-\mathrm{C}_{5} \mathrm{Me}_{5}\right) \mathrm{MCl}_{2}\right\}_{2}\right],(\mathrm{M}=\mathrm{Ir}, \mathrm{Rh})^{28}$ and the ligand dipyridyl$\mathrm{N}$-methylimine (dpNmei) and dipyridyl-N-ethylimine (dpNeti) $)^{27,29}$ were prepared according to published procedures. The ligand used in this study is shown in Figure 1.

\subsection{Preparation of complexes}

2.2a Synthesis of $\left[\left(\eta^{5}-\mathrm{C}_{5} \mathrm{Me}_{5}\right) \operatorname{Ir}\left\{\left(\mathrm{C}_{5} \mathrm{H}_{4} \mathrm{~N}\right)_{2} \mathrm{C}=\mathrm{NMe}\right\} \mathrm{Cl}\right]$ $P_{6}\left([1] \boldsymbol{P F}_{6}\right): \quad$ The complex $(0.05 \mathrm{~g}, 0.062 \mathrm{mmol}), \mathrm{NH}_{4} \mathrm{PF}_{6}$ $(0.021 \mathrm{~g}, 0.125 \mathrm{mmol})$ and dpNmei $(0.024 \mathrm{~g}, 0.125 \mathrm{mmol})$ were stirred in $\mathrm{MeOH}(30 \mathrm{~mL})$ for $15 \mathrm{~h}$. During the course of reaction, the solution turned into a dark red. The solvent was rotary evaporated and the residue was extracted with dichloromethane, and then filtered. The filtrate was concentrated to $c a .3 \mathrm{~mL}$, then excess diethyl ether was added inducing a yellow orange solid. The solid was collected, washed with diethyl ether and dried under vacuum. Yield: $0.072 \mathrm{~g}$ (\%). FTIR (KBr, cm $\left.{ }^{-1}\right): 1680,1581,1433,1346,840 ;{ }^{1} \mathrm{H}-$ NMR (DMSO- $\left.\mathrm{d}_{6}, \delta\right): 9.23(\mathrm{~d}, 1 \mathrm{H}, J=5.7), 8.92(\mathrm{~d}, 1 \mathrm{H}$, $J=4.8), 8.15$ (t, 2H, $J=8.1), 7.99$ (t, $1 \mathrm{H}, J=6.6), 7.71$ (t, $2 \mathrm{H}, J=7.8), 7.69$ (d, $1 \mathrm{H}, J=7.8), 4.02(\mathrm{~s}, 3 \mathrm{H}), 1.87$ (s, $\left.15 \mathrm{H}, \mathrm{C}_{5} \mathrm{Me}_{5}\right) ;{ }^{13} \mathrm{C}-\mathrm{NMR}\left(\mathrm{DMSO}-\mathrm{d}_{6}, \delta\right): 173.65(\mathrm{C}=\mathrm{N})$, $155.72,152.73,151.19,149.02,140.59,138.47,130.44$, $130.19,126.56,125.98,90.53$ (ring carbons, $\mathrm{C}_{5} \mathrm{Me}_{5}$ ), 47.95<smiles>[R]N=C(c1ccccn1)c1ccccn1</smiles>

$$
\begin{aligned}
& \mathrm{R}=\mathrm{Me}(\mathrm{dpNmei}) \\
& \text { or Et (dpNeti) }
\end{aligned}
$$

Figure 1. Dipyridyl-N-alkylimine ligand.
(Me, NMe), $8.81\left(\mathrm{Me}, \mathrm{C}_{5} \mathrm{Me}_{5}\right.$ ); ESI-MS: $m / z 560.1197$ $\left[\mathrm{M}-\mathrm{PF}_{6}\right]^{+}$calc. for $\mathrm{C}_{22} \mathrm{H}_{26} \mathrm{~N}_{3} \mathrm{ClIr}$ (560.1444), 524.1994 $\left[\mathrm{M}-\mathrm{PF}_{6}-\mathrm{Cl}\right]^{+}$calc. for $\mathrm{C}_{22} \mathrm{H}_{26} \mathrm{~N}_{3} \operatorname{Ir}(525.1756)$.

2.2b Synthesis of $\left[\left(\eta^{5}-\mathrm{C}_{5} \mathrm{Me}_{5}\right) \mathrm{Rh}\left\{\left(\mathrm{C}_{5} \mathrm{H}_{4} \mathrm{~N}\right)_{2} \mathrm{C}=\mathrm{NMe}\right\} \mathrm{Cl}\right]$ $\mathrm{PF}_{6}\left([2] \boldsymbol{P} \boldsymbol{F}_{6}\right):$ The complex was prepared following a similar method employed for complex ([1] $\left.\mathbf{P F}_{6}\right)$ using $\left[\mathrm{Cp} * \mathrm{RhCl}_{2}\right]_{2}$ instead of $\left[\mathrm{Cp} * \mathrm{IrCl}_{2}\right]_{2}$. FTIR $\left(\mathrm{KBr}, \mathrm{cm}^{-1}\right)$ : 1479, 1028, 840; ${ }^{1} \mathrm{H}-\mathrm{NMR}\left(\mathrm{DMSO}_{6}, \delta\right): 9.06(\mathrm{~d}, 1 \mathrm{H}, J=$ 5.1), $8.84(\mathrm{~d}, 1 \mathrm{H}, J=4.2), 8.17(\mathrm{~m}, 2 \mathrm{H}), 7.92(\mathrm{t}, 1 \mathrm{H}$, $J=6.3), 7.68(\mathrm{~m}, 2 \mathrm{H}, J=7.2), 7.42(\mathrm{~d}, 1 \mathrm{H}, J=8.1)$, $3.70(\mathrm{~s}, 3 \mathrm{H}), 1.72\left(\mathrm{~s}, 15 \mathrm{H}, \mathrm{C}_{5} \mathrm{Me}_{5}\right) ;{ }^{13} \mathrm{C}-\mathrm{NMR}$ (DMSO-d $\mathrm{d}_{6}$, $\delta): 172.06(\mathrm{C}=\mathrm{N}), 154.56,153.15,151.10,149.28,140.66$, $140.59,129.80,129.70,126.41,125.52,97.91$ (ring carbons, $\mathrm{C}_{5} \mathrm{Me}_{5}$ ), 46.46 (Me, NMe), $9.07\left(\mathrm{Me}, \mathrm{C}_{5} \mathrm{Me}_{5}\right.$ ); ESI-MS: $m / z$ $470.0498\left(\left[\mathrm{M}-\mathrm{PF}_{6}\right]^{+}\right.$calc. for $\mathrm{C}_{22} \mathrm{H}_{26} \mathrm{~N}_{3} \mathrm{ClRh}(470.0870)$ ), $434.1203\left(\mathrm{M}-\mathrm{PF}_{6}-\mathrm{Cl}\right)^{+}$calc. for $\mathrm{C}_{22} \mathrm{H}_{26} \mathrm{~N}_{3} \mathrm{Rh}$ (435.1182).

2.2c Synthesis of $\left[\left(\eta^{5}-C_{5} M e_{5}\right) \operatorname{Ir}\left\{\left(C_{5} H_{4} N\right)_{2} C=N E t\right\} C l\right] P F_{6}$ $\left([3] P F_{6}\right)$ : The complex was prepared following a similar method employed for complex ([1] $\mathbf{P F}_{\mathbf{6}}$ ) using dpNeti instead of dpNmei. FTIR (KBr, cm ${ }^{-1}$ ): 1596, 1465, 842; ${ }^{1} \mathrm{H}-\mathrm{NMR}$ $\left(\right.$ DMSO-d $\left._{6}, \delta\right): 9.01(\mathrm{~d}, 1 \mathrm{H}, J=5.4), 8.93(\mathrm{~d}, 1 \mathrm{H}, J=$ 5.4), 8.23-8.11 (m, 2H), $7.93(\mathrm{~m}, 1 \mathrm{H}), 7.87(\mathrm{~m}, 2 \mathrm{H}), 7.41$ $(\mathrm{d}, 1 \mathrm{H}, J=7.8), 4.08(\mathrm{~m}, 2 \mathrm{H}), 1.71\left(\mathrm{~s}, 15 \mathrm{H}, \mathrm{C}_{5} \mathrm{Me}_{5}\right), 1.27$ $(\mathrm{m}, 3 \mathrm{H}) ;{ }^{13} \mathrm{C}-\mathrm{NMR}\left(\mathrm{DMSO}_{6}, \delta\right): 173.91(\mathrm{C}=\mathrm{N}), 156.25$, $154.10,152.63,151.17,149.47,140.72,138.54,130.60$, $129.99,126.43,90.65$ (ring carbons, $\left.\mathrm{C}_{5} \mathrm{Me}_{5}\right), 49.35\left(\mathrm{CH}_{2}\right.$, $\left.\mathrm{N}-\mathrm{C}_{2} \mathrm{H}_{5}\right), 15.00\left(\mathrm{CH}_{3}, \mathrm{~N}-\mathrm{C}_{2} \mathrm{H}_{5}\right), 8.59\left(\mathrm{Me}, \mathrm{C}_{5} \mathrm{Me}_{5}\right)$; ESI-MS: $m / z$ 574.1595 [M-PF $]^{+}$calc. for $\mathrm{C}_{23} \mathrm{H}_{28} \mathrm{~N}_{3} \mathrm{ClIr}$ (574.1601); 538.1134 [M-PF $6-\mathrm{Cl}]^{+}$calc. for $\mathrm{C}_{23} \mathrm{H}_{28} \mathrm{~N}_{3} \operatorname{Ir}(539.1912)$.

2.2d Synthesis of $\left[\left(\eta^{5}-C_{5} M e_{5}\right) R h\left\{\left(C_{5} H_{4} N\right)_{2} C=N E t\right\} C l\right]$ $\mathrm{PF}_{6}\left([\mathbf{4}] \boldsymbol{P F}_{\mathbf{6}}\right)$ : The complex was prepared following a similar method employed for complex $\left([\mathbf{3}] \mathbf{P F}_{\mathbf{6}}\right)$ using $\left[\mathrm{Cp} * \mathrm{RhCl}_{2}\right]_{2}$ instead of $\left[\left(\mathrm{Cp}^{*} \mathrm{IrCl}_{2}\right]_{2}\right.$. FTIR $\left(\mathrm{KBr}, \mathrm{cm}^{-1}\right)$ : 1630, 1583, 1475, 1026, 844; ${ }^{1}$ H-NMR (DMSO-d $6, \delta$ ): 9.02 $(\mathrm{d}, 1 \mathrm{H}, J=5.1), 8.82(\mathrm{~s}, 1 \mathrm{H}), 8.14(\mathrm{~m}, 2 \mathrm{H}), 7.93(\mathrm{~m}, 1 \mathrm{H})$, 7.69 (t, 2H, $J=7.2), 7.26$ (d, 1H, $J=7.5), 4.06(\mathrm{~m}, 1 \mathrm{H})$, $3.84(\mathrm{~m}, 1 \mathrm{H}), 1.71$ (s, 15H, Cp*), $1.26(\mathrm{~m}, 3 \mathrm{H}) ;{ }^{13} \mathrm{C}-\mathrm{NMR}$ $\left(\right.$ DMSO $\left.^{-} \mathrm{d}_{6}, \delta\right): 172.20(\mathrm{C}=\mathrm{N}), 154.82,153.12,151.06$, $149.57,140.72,138.46,130.0,129.57,126.28,124.83$, 97.93 (ring carbon, $\left.\mathrm{C}_{5} \mathrm{Me}_{5}\right), 53.34\left(\mathrm{CH}_{2}, \mathrm{~N}-\mathrm{C}_{2} \mathrm{H}_{5}\right), 15.46$ $\left(\mathrm{CH}_{3}, \mathrm{~N}-\mathrm{C}_{2} \mathrm{H}_{5}\right), 8.89\left(\mathrm{Me}, \mathrm{C}_{5} \mathrm{Me}_{5}\right)$; ESI-MS: $m / z 484.1694$ [M-PF6]+ calc. for $\mathrm{C}_{23} \mathrm{H}_{28} \mathrm{~N}_{3} \mathrm{ClRh}$ (484.1024), 448.1222 [M-PF6-Cl] ${ }^{+}$calc. for $\mathrm{C}_{23} \mathrm{H}_{28} \mathrm{~N}_{3} \mathrm{Rh}$ (449.1338).

2.2e Synthesis of $\left[\left(\eta^{5}-C_{5} M e_{5}\right) M\left\{\left(C_{5} H_{4} N\right)_{2} C=N H\right\} C l\right] P F_{6}$ $\left(M=I r:[5] P_{F_{6}}\right.$ and $\left.R h:[6] P_{6}\right):$ Compounds were obtained as an inseparable mixture along with [1] $\mathbf{P F}_{\mathbf{6}}-[\mathbf{4}] \mathbf{P F}_{\mathbf{6}}$ by reaction of $\left[\mathrm{Cp}^{*} \mathrm{MCl}_{2}\right]_{2}(0.05 \mathrm{mmol}), \mathrm{NH}_{4} \mathrm{PF}_{6}(0.12 \mathrm{mmol})$ and dpNR $(0.12 \mathrm{mmol})$ in acetonitrile under refluxing condition for $8 \mathrm{~h}$. ESI-MS of [5] $\mathbf{P F}_{\mathbf{6}}: m / z 546.9989\left[\left(\eta^{5}-\right.\right.$ $\left.\left.\mathrm{C}_{5} \mathrm{Me}_{5}\right) \operatorname{Ir}\left\{\left(\mathrm{C}_{5} \mathrm{H}_{4} \mathrm{~N}\right)_{2} \mathrm{C}=\mathrm{NH}\right\} \mathrm{Cl}\right]^{+}\left(\mathrm{M}-\mathrm{PF}_{6}\right)^{+}$calc. for $\mathrm{C}_{21} \mathrm{H}_{24}$ $\mathrm{N}_{3}$ ClIr (546.1288); ESI-MS of [6]PF $\mathbf{P}_{6}: \mathrm{m} / z$ 421.1494, 
$\left[\left(\eta^{5}-\mathrm{C}_{5} \mathrm{Me}_{5}\right) \mathrm{Rh}\left\{\left(\mathrm{C}_{5} \mathrm{H}_{4} \mathrm{~N}\right)_{2} \mathrm{C}=\mathrm{NH}\right\}\right]^{+}\left(\mathrm{M}-\mathrm{PF}_{6}-\mathrm{Cl}\right)^{+}$calc. for $\mathrm{C}_{21} \mathrm{H}_{24} \mathrm{~N}_{3} \mathrm{Rh}$ (421.1025).

\subsection{Structure analysis and refinement}

The X-ray intensity data were measured at 293(2) K on a Bruker Smart Apex CCD area detector employing graphite monochromater using $\mathrm{M}_{0}-\mathrm{K} \alpha$ radiation $(\lambda=0.71073 \AA)$. The structures were solved by direct methods (SHELXS $97)^{30}$ and refined by full matrix least squares base on $\mathrm{F}^{2}$ using (SHELXL-97) ${ }^{31}$ software. The weighting scheme used was $\mathrm{W}=1 /\left[\sigma^{2}\left(\mathrm{~F}_{0}^{2}\right)+0.0311 \mathrm{P}^{2}+3.5016 \mathrm{P}\right]$ where $\mathrm{P}=\left(\mathrm{F}_{0}^{2}+\right.$ $2 \mathrm{~F}_{\mathrm{c}}^{2}$ )/3. Non-hydrogen atoms were refined anisotropically and hydrogen atoms were refined using a "riding" model. Refinement converged at a final $\mathrm{R}=0.0386$ for observed data $F^{2}$, and $\mathrm{wR}_{2}=0.0399$ for unique data $F^{2}$. Details of crystallographic data collection parameters and refinement are summarized in Table 1. Selected bond lengths and angles are tabulated in Table 2. Molecular structure of the compound $[\mathbf{6}] \mathbf{P F}_{\mathbf{6}}$ is shown in Figure 2.

\section{Results and Discussion}

\subsection{Synthesis and spectral characterization}

Reaction of $\left[\left\{\left(\eta^{5}-\mathrm{C}_{5} \mathrm{Me}_{5}\right) \mathrm{MCl}\right\}_{2}\right]$ with $\left(\mathrm{C}_{5} \mathrm{H}_{4} \mathrm{~N}\right)_{2} \mathrm{C}=\mathrm{NR}$ in the presence of $\mathrm{NH}_{4} \mathrm{PF}_{6}$ in methanol at room temperature yielded water soluble complexes of formulation $\left.\left[\left(\eta^{5}-\mathrm{C}_{5} \mathrm{Me}_{5}\right) \mathrm{M}\left\{\left(\mathrm{C}_{5} \mathrm{H}_{4} \mathrm{~N}\right)_{2} \mathrm{C}=\mathrm{NR}\right)\right\} \mathrm{Cl}\right](\mathrm{M}=$ $\mathrm{Rh}$ or Ir and $\mathrm{R}=\mathrm{Me}$ or Et) (Scheme 1). The complexes were isolated as their hexafluorophosphate salts and characterized on the basis of spectroscopic data (FTIR, ${ }^{1} \mathrm{H}-,{ }^{13} \mathrm{C}-\mathrm{NMR}$ and ESI-MS). Infrared spectra of the compounds displayed absorption band in the region $1638-1687 \mathrm{~cm}^{-1}$ assignable to $\mathrm{C}=\mathrm{N}$ stretching frequency. ${ }^{32}$ In all these compounds, a strong absorption band appeared in the region $840 \mathrm{~cm}^{-1}$ which is assigned to $\mathrm{PF}_{6}^{-}$counter ion. The proton NMR spectrum of complex [2] $\mathbf{P F}_{\mathbf{6}}$ showed a singlet at $\delta 1.79$ and 3.71 assignable to the methyl proton of the coordinated $\eta^{5}-\mathrm{C}_{5} \mathrm{Me}_{5}$ ligand and $\mathrm{N}-\mathrm{CH}_{3}$ group of imine ligand, respectively. In addition, signals were observed in the region of $\delta 7.48-9.08$ due to aromatic protons of the coordinated imine ligand (see SI: Figure S3). In the case of complex [1] $\mathbf{P F}_{\mathbf{6}}$, the methyl proton of the $\eta^{5}$ $\mathrm{C}_{5} \mathrm{Me}_{5}$ ligand appeared at $\delta 1.87$ whereas the methyl group of imine ligand appeared at around $\delta 4.02$ slightly downfield region compared to [2] $\mathbf{P F}_{\mathbf{6}}$. The proton NMR spectra of complexes [3] $\mathbf{P F}_{6}$ and [4] $\mathbf{P F}_{6}$ displayed a quartet at $\delta 4.05$ due to methylene proton $\left(-\mathrm{CH}_{2}-\right)$ of the imine ligand while the signal for $\eta^{5}-\mathrm{C}_{5} \mathrm{Me}_{5}$ ligand appeared at around $\delta 1.71$.

The ${ }^{13} \mathrm{C}$-NMR spectra of all these complexes showed a signal in the region of $\delta 8.59-9.07$ assignable to

Table 1. Summary of structure determination and refinement for complex $[\mathbf{6}] \mathbf{P F}_{\mathbf{6}}$.

\begin{tabular}{ll}
\hline Empirical formula & $\mathrm{C}_{21} \mathrm{H}_{24} \mathrm{Cl} \mathrm{F}_{6} \mathrm{~N}_{3} \mathrm{P} \mathrm{Rh}$ \\
CCDC & 971503 \\
Formula Weight & 601.76 \\
Temperature $(\mathrm{K})$ & $293(2)$ \\
Wavelength $(\AA)$ & 0.71073 \\
Crystal system & Orthorhombic \\
Space group & $P b c n$ \\
Unit cell dimensions & \\
$a(\AA)$ & $23.699(5)$ \\
$b(\AA)$ & $13.951(3)$ \\
$c(\AA)$ & $14.783(3)$ \\
$\alpha=\beta=\gamma$ & $90\left(^{\circ}\right)$ \\
$Z$ & 8 \\
Density (calculated) $\left(\mathrm{Mg} / \mathrm{m}^{3}\right)$ & $1.636 \mathrm{Mg} / \mathrm{m}^{3}$ \\
Absorption coefficient $\left(\mathrm{mm}^{-1}\right)$ & $0.933 \mathrm{~mm} \mathrm{~m}^{-1}$ \\
$\mathrm{~F}(000)$ & 2416 \\
$\theta$ range for data collection $\left(^{\circ}\right)$ & 1.69 to $24.47^{\circ}$ \\
index ranges & $-27 \leq h \leq 27,-16 \leq k \leq 15,-14 \leq l \leq 17$ \\
Reflection collected/unique & 17495 \\
Completeness to theta & $24.47^{\circ}$ to $98.7 \%$ \\
Refinement method & Full-matrix least squares on $F^{2}$ \\
Data/restraints/parameters & $4000 / 0 / 270$ \\
Goodness-of-fit on $F^{2}$ & 0.532 \\
Final $R$ indices & $\mathrm{R}_{1}=0.0386, \mathrm{wR} 2=0.0399$ \\
{$[I>2$ sigma $(I)]$} & \\
$R$ indices (all data) & $\mathrm{R}_{1}=0.1900, \mathrm{wR} \mathrm{R}_{2}=0.0658$ \\
Largest different peak and hole $\left(\mathrm{e} \AA^{-3}\right)$ & 0.327 and -0.292 \\
\hline &
\end{tabular}


Table 2. Selected bond lengths $(\AA)$ and angles $\left({ }^{\circ}\right)$ for $[\mathbf{6}] \mathbf{P F}_{\mathbf{6}}$.

\begin{tabular}{llll}
\hline Bond lengths $(\AA)$ & & & \\
$\mathrm{Rh}(1)-\mathrm{N}(1)$ & $2.064(6)$ & $\mathrm{Rh}(1)-\mathrm{N}(21)$ & $2.106(4)$ \\
$\mathrm{Rh}(1)-\mathrm{C}^{*}$ & 1.773 & $\mathrm{Rh}(1)-\mathrm{Cl}(1)$ & $2.397(2)$ \\
$\mathrm{Rh}(1)-\mathrm{C}(12)$ & $2.157(3)$ & $\mathrm{Rh}(1)-\mathrm{C}(14)$ & $2.131(5)$ \\
$\mathrm{Rh}(1)-\mathrm{C}(11)$ & $2.158(5)$ & $\mathrm{Rh}(1)-\mathrm{C}(13)$ & $2.115(6)$ \\
$\mathrm{Rh}(1)-\mathrm{C}(15)$ & $2.132(5)$ & $\mathrm{C}(31)-\mathrm{N}(32)$ & 1.3900 \\
$\mathrm{C}(22)-\mathrm{N}(21)$ & 1.3900 & $\mathrm{C}(26)-\mathrm{N}(21)$ & 1.3900 \\
$\mathrm{~N}(1)-\mathrm{H}(1)$ & 0.8600 & $\mathrm{C}(2)-\mathrm{C}(22)$ & $1.440(10)$ \\
$\mathrm{C}(2)-\mathrm{C}(31)$ & $1.429(8)$ & $\mathrm{C}(2)-\mathrm{N}(1)$ & $1.261(10)$ \\
Bond angles $\left(^{\circ}\right)$ & & & \\
$\mathrm{N}(21)-\mathrm{Rh}(1)-\mathrm{N}(1)$ & $74.8(3)$ & $\mathrm{C}(2)-\mathrm{N}(1)-\mathrm{Rh}(1)$ & $120.3(6)$ \\
$\mathrm{N}(1)-\mathrm{Rh}(1)-\mathrm{Cl}(1)$ & $87.28(19)$ & $\mathrm{N}(21)-\mathrm{Rh}(1)-\mathrm{Cl}(1)$ & $90.95(15)$ \\
$\mathrm{C}(22)-\mathrm{N}(21)-\mathrm{Rh}(1)$ & $115.8(4)$ & $\mathrm{C}(22)-\mathrm{C}(2)-\mathrm{N}(1)$ & $116.5(7)$ \\
$\mathrm{C}(2)-\mathrm{C}(31)-\mathrm{C}(36)$ & $121.0(7)$ & $\mathrm{C}(26)-\mathrm{N}(21)-\mathrm{Rh}(1)$ & $124.0(3)$ \\
\hline
\end{tabular}

$\mathrm{C}^{*}=$ Centroid of $\mathrm{C}(11), \mathrm{C}(12), \mathrm{C}(13), \mathrm{C}(14), \mathrm{C}(15)$.
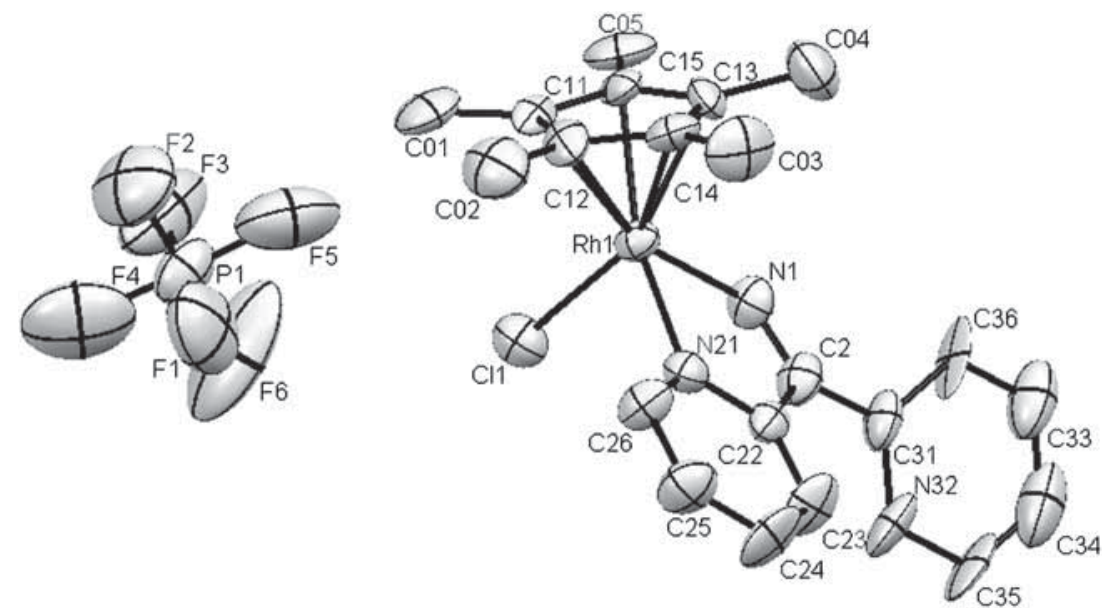

Figure 2. Molecular structure of $\left[\left(\eta^{5}-\mathrm{C}_{5} \mathrm{Me}_{5}\right) \mathrm{Rh}\left\{\left(\mathrm{C}_{5} \mathrm{H}_{4} \mathrm{~N}\right)_{2} \mathrm{C}=\mathrm{NH}\right\} \mathrm{Cl}\right] \mathrm{PF}_{6}$, $[6] \mathbf{P F}_{\mathbf{6}}$. Hydrogen atoms have been omitted for clarity.

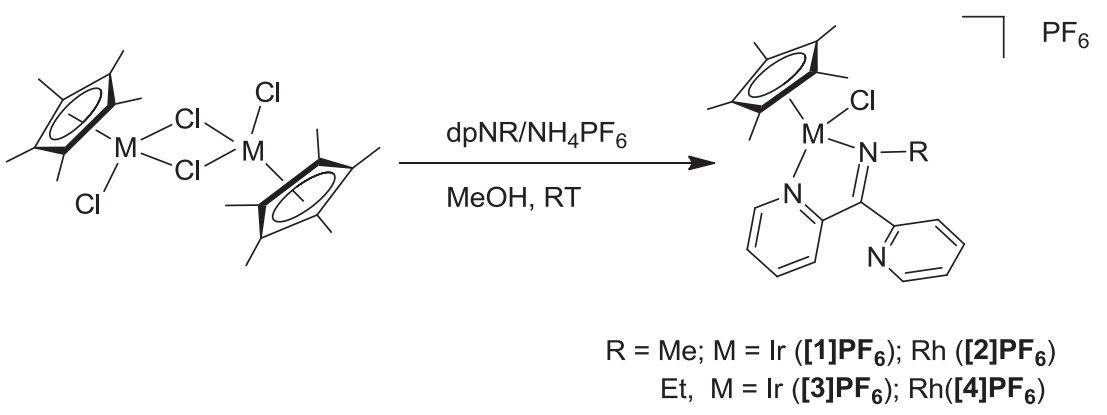

Scheme 1. Reaction pathways for the preparation of the complexes.

the methyl carbon of $\eta^{5}-\mathrm{C}_{5} \mathrm{Me}_{5}$ ligand. The signal for the ring carbons of $\eta^{5}-\mathrm{C}_{5} \mathrm{Me}_{5}$ ligand appeared at around $\delta 90.5$ for iridium(III) complexes [1] $\mathbf{P F}_{\mathbf{6}}$ and [3] $\mathbf{P F}_{6}$ in contrast at a much downfield region at around $\delta 97.6$ for rhodium(III) complexes [2] $\mathbf{P F}_{\mathbf{6}}$ and [4] $\mathbf{P F}_{\mathbf{6}}$. Further, ${ }^{13} \mathrm{C}$-NMR spectrum of the complexes showed signals for aromatic carbons in the region of $\delta 126-$ 156 due to ring carbons of the coordinating ligand while the signal for $\mathrm{C}=\mathrm{N}$ group of the imine ligand appeared in the region of $\delta 172.06-173.65$. The ${ }^{13} \mathrm{C}$ NMR spectrum of [1] $\mathbf{P F}_{\mathbf{6}}$, displayed a signal at $\delta 47.95$ assignable to methyl group of the imine ligand $(\mathrm{N}$ $\mathrm{Me})$ which is slightly downfield to that of analogous rhodium complex [2] $\mathbf{P F}_{6}$ where the signal appeared at $\delta$ 46.46. ${ }^{1} \mathrm{H}$ and ${ }^{13} \mathrm{C}$-NMR-spectroscopic data are in accordance with the formula of these complexes. 
The structure of these complexes were further supported by ESI-MS spectral data analysis. Mass spectra of the complexes showed prominent molecular ion peaks corresponding to $\left[\mathrm{M}-\mathrm{PF}_{6}\right]^{+}$and $\left[\mathrm{M}-\mathrm{PF}_{6}-\mathrm{Cl}\right]^{+}$. For instance, ESI-MS spectrum of complex [1] $\mathbf{P F}_{\mathbf{6}}$ showed peaks at $m / z=559$ and 524 corresponding to $\left(\left[\left(\eta^{5}-\mathrm{C}_{5} \mathrm{Me}_{5}\right) \operatorname{Ir}\left\{\left(\mathrm{C}_{5} \mathrm{H}_{4} \mathrm{~N}\right)_{2} \mathrm{C}=\mathrm{N}-\mathrm{Me}\right\} \mathrm{Cl}\right]\right)^{+}\left[\mathrm{M}-\mathrm{PF}_{6}\right]^{+}$ and $\left(\left[\left(\eta^{5}-\mathrm{C}_{5} \mathrm{Me}_{5}\right) \operatorname{Ir}\left\{\left(\mathrm{C}_{5} \mathrm{H}_{4} \mathrm{~N}\right)_{2} \mathrm{C}=\mathrm{N}-\mathrm{Me}\right\}\right]^{+}\left[\mathrm{M}-\mathrm{PF}_{6}-\mathrm{Cl}\right]^{+}\right.$. Mass spectra of the complexes [2] $\mathbf{P F}_{6}-[\mathbf{4}] \mathbf{P F}_{6}$ also showed a similar pattern of molecular ion peaks due to $\left[\mathrm{M}-\mathrm{PF}_{6}\right]^{+}$and $\left[\mathrm{M}-\mathrm{PF}_{6}-\mathrm{Cl}\right]^{+}$(see Experimental section). Spectroscopic data of the complexes $[\mathbf{1}] \mathbf{P F}_{\mathbf{6}}-[\mathbf{4}] \mathbf{P F}_{\mathbf{6}}$ were well matched with the proposed structures of the compounds.

Interestingly, when the reaction of $\left[\mathrm{MCl}_{2}\left(\eta^{5}-\mathrm{C}_{5} \mathrm{Me}_{5}\right)\right]_{2}$ and $-\left(\mathrm{C}_{5} \mathrm{H}_{4} \mathrm{~N}\right)_{2} \mathrm{C}=\mathrm{NMe}$ was performed in acetonitrile under refluxing condition, complexes $\left[\left(\eta^{5}-\mathrm{C}_{5} \mathrm{Me}_{5}\right)\right.$ $\left.\mathrm{M}\left\{\left(\mathrm{C}_{5} \mathrm{H}_{4} \mathrm{~N}\right)_{2} \mathrm{C}=\mathrm{N}-\mathrm{Me}\right\} \mathrm{Cl}\right] \mathrm{PF}_{6}\left(\mathrm{M}=\mathrm{Ir}[\mathbf{1}] \mathrm{PF}_{\mathbf{6}} ; \mathrm{Rh}=\right.$ [2] $\mathbf{P F}_{6}$ ) were obtained along with inseparable complexes, $\left[\left(\eta^{5}-\mathrm{C}_{5} \mathrm{Me}_{5}\right) \mathrm{M}\left\{\left(\mathrm{C}_{5} \mathrm{H}_{4} \mathrm{~N}\right)_{2} \mathrm{C}=\mathrm{NH}\right\} \mathrm{Cl}\right] \mathrm{PF}_{6}(\mathrm{M}=\mathrm{Ir}$, [5] $\mathbf{P F}_{\mathbf{6}} ; \mathrm{Rh},[\mathbf{6}] \mathbf{P F}_{\mathbf{6}} ;$ Scheme 2). Under similar reaction condition $\left[\mathrm{MCl}_{2}\left(\eta^{5}-\mathrm{C}_{5} \mathrm{Me}_{5}\right)\right]_{2}$ reacts with $-\left(\mathrm{C}_{5} \mathrm{H}_{4} \mathrm{~N}\right)_{2}$ $\mathrm{C}=\mathrm{N}$-Et to give [3] $\mathbf{P F}_{6}$ and [4] $\mathbf{P F}_{6}$ along with minor quantity of the compound [5] $\mathbf{P F}_{6}$ and $[\mathbf{6}] \mathbf{P F}_{6}$ (Scheme 2).

Attempt to isolate these $\mathrm{NH}$-ketimine compounds $\left[\left(\eta^{5}-\mathrm{C}_{5} \mathrm{Me}_{5}\right) \mathrm{M}\left\{\left(\mathrm{C}_{5} \mathrm{H}_{4} \mathrm{~N}\right)_{2} \mathrm{C}=\mathrm{NH}\right\} \mathrm{Cl}\right] \mathrm{PF}_{6} \quad\left([5] \mathbf{P F}_{6}\right.$ and $[6] \mathbf{P F}_{6}$ ) was unsuccessful in our hands. However, formation of a mixture of the dipyridyl-N-alkylimine and dipyridyl-NH-ketimine compounds was readily evident from the proton NMR spectra of the compounds. The proton NMR spectra showed signals for alkyl group (Me or Et) of the dipyridyl-Nalkylimine ligand as well a signal due to ketimine group (=NH-) in the region $\delta 3.89-4.03^{27}$ and $11.37-$ $13.57,{ }^{24}$ respectively, indicating presence of both the species. Formation of a mixture of dipyridyl$\mathrm{N}$-alkylimine and dipyridyl-NH-ketimine compounds was further supported by mass spectral data. For instance, the mass spectra of rhodium(III) complexes obtained by the reaction of $\left[\left\{\eta^{5}-\mathrm{C}_{5} \mathrm{Me}_{5}\right) \mathrm{RhCl}_{2}\right]_{2}$ and the dipyridyl ligand, $\left(\mathrm{C}_{5} \mathrm{H}_{4} \mathrm{~N}\right)_{2} \mathrm{C}=\mathrm{N}-\mathrm{Me}$ in refluxing acetonitrile showed fragmentation of molecular ion peaks at $m / z=470$ and 435 due to $\left(\left[\left(\eta^{5}-\mathrm{C}_{5} \mathrm{Me}_{5}\right) \mathrm{Rh}\right.\right.$ $\left.\left.\left\{\left(\mathrm{C}_{5} \mathrm{H}_{4} \mathrm{~N}\right)_{2} \mathrm{C}=\mathrm{N}-\mathrm{Me}\right\} \mathrm{Cl}\right]\right)^{+}\left([2] \mathrm{PF}_{6}-\mathrm{PF}_{6}\right)^{+}$and $\left(\left[\left(\eta^{5}-\right.\right.\right.$ $\left.\left.\left.\mathrm{C}_{5} \mathrm{Me}_{5}\right) \mathrm{Rh}\left\{\left(\mathrm{C}_{5} \mathrm{H}_{4} \mathrm{~N}\right)_{2} \mathrm{C}=\mathrm{N}-\mathrm{Me}\right\}\right]\right)^{+} \quad\left([2] \mathrm{PF}_{6}-\mathrm{PF}_{6}-\mathrm{Cl}\right)^{+}$ (see Supplementary Information). In addition, the spectrum also showed peak at $m / z 421$ due to $\left(\left[\left(\eta^{5}-\mathrm{C}_{5} \mathrm{Me}_{5}\right)\right.\right.$ $\left.\left.\mathrm{Rh}\left\{\left(\mathrm{C}_{5} \mathrm{H}_{4} \mathrm{~N}\right)_{2} \mathrm{C}=\mathrm{NH}\right\}\right]\right)^{+}\left([\mathrm{M}]-\mathrm{PF}_{6}-\mathrm{Cl}\right)^{+}$indicating the reaction also produces rhodium(III) ketimine compound [6] $\mathbf{P F}_{6}$ along with the rhodium(III) dipyridyl$\mathrm{N}$-alkylimine compound [2] $\mathbf{P F}_{\mathbf{6}}$. When the ligand, $\left(\mathrm{C}_{5} \mathrm{H}_{4} \mathrm{~N}\right)_{2} \mathrm{C}=\mathrm{N}$-Et was used, the molecular ion peaks were observed at $\mathrm{m} / z \quad 484$ and 448 corresponding to $\left[\left(\eta^{5}-\mathrm{C}_{5} \mathrm{Me}_{5}\right) \mathrm{Rh}\left\{\left(\mathrm{C}_{5} \mathrm{H}_{4} \mathrm{~N}\right)_{2} \mathrm{C}=\mathrm{N}-\mathrm{Et}\right\} \mathrm{Cl}\right]^{+}\left([4] \mathrm{PF}_{6}-\mathrm{PF}_{6}\right)^{+}$ and $\left[\left(\eta^{5}-\mathrm{C}_{5} \mathrm{Me}_{5}\right) \mathrm{Rh}\left\{\left(\mathrm{C}_{5} \mathrm{H}_{4} \mathrm{~N}\right)_{2} \mathrm{C}=\mathrm{N}-\mathrm{Et}\right\}\right]^{+}\left([4] \mathbf{P F}_{6}-\mathrm{PF}_{6^{-}}\right.$ $\mathrm{Cl})^{+}$, respectively, in addition to peak at $\mathrm{m} / z 421$ due to $\left([\mathbf{6}] \mathbf{P F}_{6}-\mathrm{PF}_{6}-\mathrm{Cl}\right)^{+}$. Notably, the molecular ion peak at $m / z \quad 421$ corresponding to $\left[\left(\eta^{5}-\mathrm{C}_{5} \mathrm{Me}_{5}\right) \mathrm{Rh}\right.$ $\left.\left\{\left(\mathrm{C}_{5} \mathrm{H}_{4} \mathrm{~N}\right)_{2} \mathrm{C}=\mathrm{NH}\right\} \mathrm{Cl}\right]^{+}\left([\mathbf{6}] \mathbf{P F}_{6}-\mathrm{PF}_{6}-\mathrm{Cl}\right)^{+}$was observed irrespective of the ligand, $\left(\mathrm{C}_{5} \mathrm{H}_{4} \mathrm{~N}\right)_{2} \mathrm{C}=\mathrm{N}-\mathrm{Me}$ or $\left(\mathrm{C}_{5} \mathrm{H}_{4} \mathrm{~N}\right)_{2} \mathrm{C}=\mathrm{N}$-Et was used, suggesting a degradation of methyl or ethyl group $(=\mathrm{N}-\mathrm{R})$ and formation of [6] $\mathbf{P F}_{6}$, where the transformed ligand, $\left(\mathrm{C}_{5} \mathrm{H}_{4} \mathrm{~N}\right)_{2} \mathrm{C}=\mathrm{NH}$ is coordinated to the rhodium atom.

Similarly, mass spectrum of iridium complexes obtained by the reaction of $\left[\left(\eta^{5}-\mathrm{C}_{5} \mathrm{Me}_{5}\right) \mathrm{IrCl}_{2}\right]_{2}$ and $-\left(\mathrm{C}_{5} \mathrm{H}_{4} \mathrm{~N}\right)_{2} \mathrm{C}=\mathrm{N}-\mathrm{R}(\mathrm{R}=\mathrm{Me}$ or Et) in refluxing acetonitrile showed similar pattern of fragmentations and peaks were observed at $m / z=574,560,538,524$ corresponding to $\left[\left(\eta^{5}-\mathrm{C}_{5} \mathrm{Me}_{5}\right) \operatorname{Ir}\left\{\left(\mathrm{C}_{5} \mathrm{H}_{4} \mathrm{~N}\right)_{2} \mathrm{C}=\mathrm{NEt}\right\} \mathrm{Cl}\right]^{+}$ $\left(\mathrm{M}-\mathrm{PF}_{6}\right)^{+},\left[\left(\eta^{5}-\mathrm{C}_{5} \mathrm{Me}_{5}\right) \operatorname{Ir}\left\{\left(\mathrm{C}_{5} \mathrm{H}_{4} \mathrm{~N}\right)_{2} \mathrm{C}=\mathrm{NMe}\right\} \mathrm{Cl}\right]^{+}(\mathrm{M}-$ $\left.\mathrm{PF}_{6}\right]^{+},\left[\left(\eta^{5}-\mathrm{C}_{5} \mathrm{Me}_{5}\right) \operatorname{Ir}\left\{\left(\mathrm{C}_{5} \mathrm{H}_{4} \mathrm{~N}\right)_{2} \mathrm{C}=\mathrm{NEt}\right\} \mathrm{Cl}\right]^{+}\left(\mathrm{M}-\mathrm{PF}_{6}-\mathrm{Cl}\right)^{+}$ and $\left[\left(\eta^{5}-\mathrm{C}_{5} \mathrm{Me}_{5}\right) \operatorname{Ir}\left\{\left(\mathrm{C}_{5} \mathrm{H}_{4} \mathrm{~N}\right)_{2} \mathrm{C}=\mathrm{NMe}\right\}\right]^{+}\left(\mathrm{M}-\mathrm{PF}_{6}-\mathrm{Cl}\right)^{+}$, respectively. Additionally, spectra also showed a common peak at around $m / z 546$ and 510 due to $\left[\left(\eta^{5}-\mathrm{C}_{5} \mathrm{Me}_{5}\right)\right.$ $\left.\operatorname{Ir}\left\{\left(\mathrm{C}_{5} \mathrm{H}_{4} \mathrm{~N}\right)_{2} \mathrm{C}=\mathrm{NH}\right\} \mathrm{Cl}\right]^{+}\left(\mathrm{M}-\mathrm{PF}_{6}\right)^{+}$and $\left[\left(\eta^{5}-\mathrm{C}_{5} \mathrm{Me}_{5}\right)\right.$ $\left.\operatorname{Ir}\left\{\left(\mathrm{C}_{5} \mathrm{H}_{4} \mathrm{~N}\right)_{2} \mathrm{C}=\mathrm{NR}\right\}\right]^{+}\left(\mathrm{M}-\mathrm{PF}_{6}-\mathrm{Cl}\right)^{+}$which suggest coordination of rare fragment, $\left(\mathrm{C}_{5} \mathrm{H}_{4} \mathrm{~N}\right)_{2} \mathrm{C}=\mathrm{NH}$ to the iridium centre. Mass spectral data unambiguously confirmed the formation of NH-ketimine compound [5] $\mathbf{P F}_{\mathbf{6}}$ and $[6] \mathbf{P F}_{6}$. The authenticity of the NH-ketimine complexes was established by single X-ray structure of [6] $\mathbf{P F}_{6}$. Structure showed that the rhodium atom is

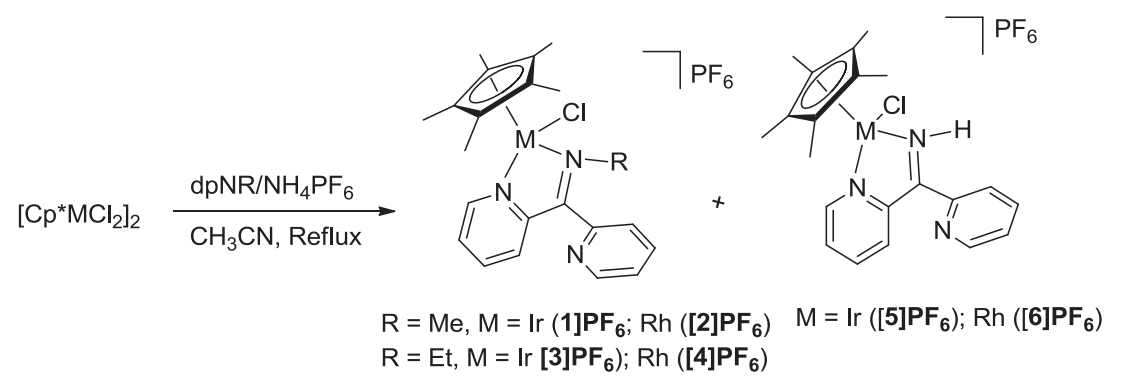

Scheme 2. Reaction pathways for the preparation of the complexes. 
coordinated by a transformed ligand $\left(\mathrm{C}_{5} \mathrm{H}_{4} \mathrm{~N}\right)_{2} \mathrm{C}=\mathrm{NH}$ which is believed to be formed via $\mathrm{N}-\mathrm{C}$ bond cleavage.

It is noteworthy that hydrolysis of coordinated imine ligand in metal complexes usually occurred with a cleavage of $\mathrm{C}=\mathrm{N}$ bond. ${ }^{21,22}$ Although cleavage of single $\mathrm{C}-\mathrm{N}$ single bond is rare, transition metal could catalyse cleavage of $\mathrm{C}-\mathrm{N}$ single bond for a various functionalities. ${ }^{33}$ Further, cleavage of $\mathrm{C}-\mathrm{N}$ single bond is not restricted only to the coordinated imine ligands but such a cleavage was also observed in alkylimine fragment in a ferrocene compound. ${ }^{34}$ Thus, it was observed that one of the methyl group in $\mathrm{FcCH}_{2} \mathrm{NMe}_{2}$ was degraded to form a sub product, $\mathrm{FcCH}_{2} \mathrm{NHMe}$ during the catalytic reaction of $\mathrm{FcCH}_{2} \mathrm{NMe}_{2}$ with diphenylacetylene $(\mathrm{Fc}=$ ferrocene $) .{ }^{34}$ In this present study, we demonstrated that iridium(III) and rhodium(III) could also mediate cleavage of $\mathrm{C}-\mathrm{N}$ single bond of a coordinated imine ligand and formed their corresponding ketimine compounds. Characterization of dipyridyl-Nalkylimine complexes [1] $\mathbf{P F}_{\mathbf{6}}-[\mathbf{4}] \mathbf{P F}_{\mathbf{6}}$ was achieved by ${ }^{1} \mathrm{H},{ }^{13} \mathrm{C}-\mathrm{NMR}$ and ESI-MS data whereas, dipyridyl-NHketimine compounds [5] $\mathbf{P F}_{\mathbf{6}}$ and [6] $\mathbf{P F}_{\mathbf{6}}$ were mainly characterized by ESI-MS data. The molecular structure of one $\mathrm{NH}$-ketimine compound [6] $\mathbf{P F}_{6}$ was determined by single crystal X-ray diffraction.

\subsection{Crystal structure of $[\mathbf{6}] \boldsymbol{P F}_{\mathbf{6}}$}

Complex [6] $\mathbf{P F}_{\mathbf{6}}$ crystallizes in orthorhombic space group $\mathrm{Pbcn}$ with an average $\mathrm{Rh}-\mathrm{C}$ bond distance of $2.138 \AA$, while the distance between rhodium and centroid of $\mathrm{C}_{5} \mathrm{Me}_{5}$ ring is $1.773 \AA$. Crystal structure consists of mononuclear cationic unit $\left[\left(\eta^{5}-\mathrm{C}_{5} \mathrm{Me}_{5}\right)\right.$ $\left.\mathrm{Rh}\left\{\left(\mathrm{C}_{5} \mathrm{H}_{4} \mathrm{~N}\right)_{2} \mathrm{C}=\mathrm{NH}\right\} \mathrm{Cl}\right]^{+}$and the hexafluorophosphate anion $\left(\mathrm{PF}_{6}^{-}\right)$. The geometry around the rhodium atom can be regarded as pseudo-octahedral with $\eta^{5}-\mathrm{C}_{5} \mathrm{Me}_{5}$ ligand occupying three coordination sites, $\pi$-bonded to the rhodium atom in $\eta^{5}$-fashion while the remaining coordination sites were occupied by one chlorine atom and the two nitrogen atoms of the coordinated dipyridyl ligand. There is significant delocalization of pi electron in the five membered ring as evident from equal bond distances of $\mathrm{C}-\mathrm{C}$ bond in the ring. The $\mathrm{Rh}-\mathrm{N}$ bond distances of $\mathrm{Rh}(1)-\mathrm{N}(1)$ and $\mathrm{Rh}(1)-\mathrm{N}(21)$ are 2.064(6) and 2.106(4) $\AA$, respectively, comparable with those reported Rh-N bond length (Table 2). ${ }^{35}$ The molecule adopts well-known piano stool structure with the bite angle of $\mathrm{N}(1)-\mathrm{Rh}(1)-\mathrm{N}(21)$ as $74.8(3) \AA$, which is very close to those observed in the related rhodium(III) compounds. ${ }^{35,36}$ Further, the $\mathrm{Rh}-\mathrm{Cl}$ bond length $2.397(2) \AA$ is comparable to the reported $\mathrm{Rh}-\mathrm{Cl}$ bond length 2.3984(1) $\AA .{ }^{35}$ In the structure, the $\mathrm{PF}_{6}^{-}$ion adopts octahedral geometry with an average P-F bond distance of $1.534(7) \AA$.

\section{Conclusions}

This paper describes synthesis of iridium(III) and rhodium(III) complexes containing dipyridyl-N-alkylimine ligands of formula $\left[\left(\eta^{5}-\mathrm{C}_{5} \mathrm{Me}_{5}\right) \mathrm{M}\left\{\left(\mathrm{C}_{5} \mathrm{H}_{4} \mathrm{~N}\right)_{2} \mathrm{C}=\mathrm{NR}\right\} \mathrm{Cl}\right]$ $\mathrm{PF}_{6}$ and formation of dipyridyl-NH-ketimine compounds of the type $\left[\left(\eta^{5}-\mathrm{C}_{5} \mathrm{Me}_{5}\right) \mathrm{M}\left\{\left(\mathrm{C}_{5} \mathrm{H}_{4} \mathrm{~N}\right)_{2} \mathrm{C}=\mathrm{NH}\right\} \mathrm{Cl}\right] \mathrm{PF}_{6}$. Iridium(III) and rhodium(III) dipyridyl-N-alkylimine compounds [1] $\mathbf{P F}_{6}-[4] \mathbf{P F}_{6}$ were formed as the only product when the reaction of $\left[\left(\eta^{5}-\mathrm{C}_{5} \mathrm{Me}_{5}\right) \mathrm{MCl}_{2}\right]_{2}$ and dipyridyl ligands (dpNmei or dpNeti) was carried out in methanol at room temperature. In contrast, a mixture of [1] $\mathbf{P F}_{6}$-[4] $\mathbf{P F}_{6}$ along with inseparable iridium(III) and rhodium(III) NH-ketimine compounds [5] $\mathbf{P F}_{\mathbf{6}}$ and [6] $\mathbf{P F}_{6}$ were obtained when the reaction was performed at elevated temperature in refluxing acetonitrile. The dipyridyl-N-alkylimine compounds $[\mathbf{1}] \mathbf{P F}_{\mathbf{6}}-[\mathbf{4}] \mathbf{P F}_{\mathbf{6}}$ were characterized on the basis of spectroscopic data (FTIR, ${ }^{1} \mathrm{H},{ }^{13} \mathrm{C}-\mathrm{NMR}$ and ESI-MS data). Whereas, characterization of $\mathrm{NH}$-ketimine compounds [5] $\mathbf{P F}_{\mathbf{6}}$ and $[\mathbf{6}] \mathbf{P F}_{\mathbf{6}}$ were mainly achieved by ESI-MS mass spectral data. Crystal structure of one rhodium NHketimine compound $[\mathbf{6}] \mathbf{P F}_{\mathbf{6}}$ has been determined by $\mathrm{X}$-ray crystallography.

\section{Supplementary Information (SI)}

CCDC No. 971503 contains the supplementary crystallography data for this paper. Copies of this information may be obtained free of charge from the Cambridge Crystallography Data Centre via www.ccdc.cam.ac.uk/data request/cif. Additional information pertaining to characterization of compounds such as copies of ${ }^{1} \mathrm{H},{ }^{13} \mathrm{C}-\mathrm{NMR}$ and ESI-MS spectra of compounds, Table of bond lengths and angles for the crystal structure of [6] $\mathbf{P F}_{\mathbf{6}}$ are available as supporting information at www.ias.ac.in/chemsci.

\section{Acknowledgement}

KSS thanks the Department of Science and Technology (SR/FT/CS-001/2010) India for financial support.

\section{References}

1. Leung C H, Zhong H J, Chan D S H and Ma D L 2013 Bioactive iridium and rhodium complexes as therapeutic agents Coord. Chem. Rev. 2571764

2. Geldmacher Y, Oleszak M and Sheldrick W S 2012 Rhodium(III) and iridium(III) complexes as anticancer agents Inorg. Chim. Acta $\mathbf{3 9 3} 84$ 
3. Yellol G S, Donaire A, Yellol J G, Vasylyeva V, Christoph J and Ruiz J 2013 On the antitumor properties of novel cyclometalated benzimidazole $\mathrm{Ru}(\mathrm{II}), \mathrm{Ir}(\mathrm{III})$ and Rh(III) complexes Chem. Commun. 4911533

4. Liu Z and Sadler P J 2014 Organoiridium complexes: Anticancer agents and catalysts Acc. Chem. Res. 471174

5. Wetzel A, Wockel S, Schelwies M, Brinks M K, Rominger F, Hofmann P and Limbach M 2013 Selective alkylation of amines with alcohols by $\mathrm{Cp}^{*}$-Iridium(III) half-sandwich complexes Org. Lett. 15266

6. Matharu D S, Morris D J, Kawamoto A M, Clarkson G J and Wills M 2005 A stereochemically well-defined rhodium(III) catalyst for asymmetric transfer hydrogenation of ketones Org. Lett. 75489

7. Lalrempuia R, Iglesias M, Polo V, Sanz M P J, Fernndez-Alvarez F J, Pérez-Torrente J J and Oro L A 2012 Effective fixation of $\mathrm{CO}_{2}$ by iridium-catalyzed hydrosilylation Angew. Chem. 12412996

8. Park S H, Park Y and Chang S 2014 Rhodium-catalyzed direct amination of arene $\mathrm{C}-\mathrm{H}$ bonds using azides as the nitrogen sourc Org. Synth. 9152

9. Song G, Wang F and Li X 2012 C-C, C-O and C-N bond formation via rhodium(III) catalyzed oxidative C-H activation Chem. Soc. Rev. 413651

10. Satoh T and Miura M 2010 Oxidative coupling of aromatic substrates with alkynes and alkenes under rhodium catalysis Chem. Eur. J. 1611212

11. Carmona D, Lamata M P, Viguri F, Rodriguez R, Lahoz F J, Dobrinovitch I T and Oro L A 2007 Pentamethylcyclopentadienyl-iridium(III) complexes with pyridylaminoligands: Synthesis and applications as asymmetric catalysts for Diel-Alder reactions Dalton Trans. 1911

12. Liu Z, Romero-Canelón I, Habtemariam A, Clarkson G J and Sadler P J 2014 Potent half-sandwich iridium(III) anticancer complexes containing $\mathrm{C}^{\wedge} \mathrm{N}$-chelated and pyridine ligands Organometallics 335324

13. Hearn J M, Romero-Canelón I, Qamar B, Liu Z, Hands-Portman I and Sadler P J 2013 Organometallic iridium(III) anticancer complexes with new mechanisms of action: NCI-60 screening, mitochondrial targeting, and apoptosis ACS Chem. Biol. 81335

14. Liu Z, Habtemariam A, Pizarro A M, Fletcher S A, Kisova A, Vrana O, Salassa L, Bruijnincx P C, Clarkson G J, Brabec V and Sadler P J 2011 Organometallic HalfSandwich Iridium Anticancer Complexes J. Med. Chem. 543011

15. Gençaslan S and Sheldrick W S 2005 Bifunctional Bioorganometallic Iridium(III-Platinum(II) Complexes Incorporating Both Intercalative and Covalent DNA Binding Capabilities Eur. J. Inorg. Chem. 3840

16. Herebian D and Sheldrick W S 2002 Synthesis and DNA binding properties of bioorganometallic $\left(\eta^{5}\right.$-pentamethylcyclo-pentadienyl)iridium(III) complexes of the type $\left.\left[\eta^{5}-\mathrm{C}_{5} \mathrm{Me}_{5}\right) \operatorname{Ir}(\mathrm{Aa})(\mathrm{dppz})\right]^{n+}(\mathrm{dppz}=$ dipyrido $\left[3,2-a: 2^{\prime}, 3^{\prime}-c\right]$-phenazine, $\left.n=1-3\right)$, with S-coordinated amino acids (Aa) orpeptides J. Chem. Soc. Dalton Trans. 966

17. Govindaswamy P, Carroll P J, Mozharivskyj Y and Kollipara M R 2006 Substitution reactions of diphenyl2-pyridylphosphine with $\left[\left(\eta^{5}-\mathrm{C}_{5} \mathrm{Me}_{5}\right) \mathrm{M}(\mu-\mathrm{Cl}) \mathrm{Cl}\right]_{2}$ $(\mathrm{M}=\mathrm{Rh}$ or $\mathrm{Ir})$ dimers: Isolation of mono-,di- and chelating complexes J. Chem. Sci. 118319
18. Govindaswamy P, Linder D, Lacour J, Suss-Fink G and Therrien B 2007 Chiral or not chiral? A case study of the hexanuclear metalloprisms $\left[\mathrm{Cp}^{*}{ }_{6} \mathrm{M}_{6}(\mu \text {-tpt- } k \mathrm{~N})_{2}(\mu-\right.$ $\left.\left.\mathrm{C}_{2} \mathrm{O}_{4}-k \mathrm{O}\right)_{3}\right]^{6+}(\mathrm{M}=\mathrm{Rh}, \mathrm{Ir}, \mathrm{tpt}=2,4,6$-tri(pyridin-4-yl)1,3,5-triazine) Dalton Trans. 4457

19. Han Y-F, Jia W-G, Lin Y-J and Jin G-X 2009 Extending rectangular meta-organic frameworks to the third dimension: Discrete organometallic boxes for reversible trapping of halocarbons occurring with conservation of the lattice Angew. Chem. 486234

20. Shen X-Y, Zhang L, Lin Y-J and Jin G-X 2014 Construction of iridium and rhodium cyclometalated macrocycles based onp-carborane and N,N'-donor bridging ligands Dalton Trans. 4317200

21. Geng J, Zhang K, Peng Y-X, Wang L and Huang W 2014 A ruthenium(II) complex having a ligand undergoing partial $\mathrm{C}=\mathrm{N}$ cleavage and unusual double-bond shift and nonchirality Inorg. Chem. Commun. 40112

22. Prasad K T, Gupta G, Rao A V, Das B and Kollipara M R 2009 New series of platinum group metal complexes bearing $\eta^{5}$ - and $\eta^{6}$-cyclichydrocarbons and Schiff base derived from 2-acetylthiazole: Syntheses and structural studies Polyhedron 282649

23. Albert J, Cadena J M, González A, Granell J, Solans $\mathrm{X}$ and Font-Bardia M 2003 The first NH aldimine organometallic compound. Isolation and crystal structure Chem. Commun. 528

24. Chakraborty S, Walawalkar M G and Lahiri G K 2001 Ruthenium-mediated selective cleavage of nitrogecarbon bondof the diimine function. Synthesis, spectroscopic and redoxproperties of the complexes $\left[\mathrm{Ru}(\mathrm{L})_{2}\right.$ $\left.\left\{-\mathrm{OC}_{6} \mathrm{H}_{4} \mathrm{C}\left(\mathrm{CH}_{3}\right)=\mathrm{N}-\mathrm{H}\right\}\right]\left[\mathrm{ClO}_{4}\right]\left(\mathrm{L}=2,2^{\prime}\right.$-bipyridine and 1,10-phenanthroline) and the crystal structure of the bipyridine derivative Polyhedron 201851

25. Chakraborty S, Mondal B, Sarkar B and Lahiri G K 2002 Bridging function mediated intermetallic coupling in diruthenium-bis(bipyridine) complexes J. Chem. Sci. 114443

26. Chakraborty S, Walawalkar M G and Lahiri G K 2000 Ruthenium(II)/(III) bipyridine heterochelates incorporatingphenolato imine functionalities. Synthesis, crystal structure, spectroscopic and electron-transfer properties and solution reactivities Dalton Trans. 2875

27. Singh K S and Kaminsky W 2011 Synthesis, spectral and structural studies of water soluble arene ruthenium(II)complexes containing 2,20-dipyridyl-Nalkylimine ligand Inorg. Chim. Acta 365487

28. White C, Yates A and Maitlis P M 1992 AAA $\eta^{5}$ pentamethylcyclopentadienyl) Rhodium and -Iridium compounds Inorg. Synth. 29228

29. Flores-Chavez B, Martinez-Ortega B A, AlvaradoRodriguez J G and Andrade-Lopez N 2005 Synthesis, characterization and crystal structures of dipyridyl- $N$ methylimine and cloro-bis $(N, N$-2,2-dipyridyl-N-methylimine)lithium complex J. Chem. Cryst. 35221

30. SHELXS-97: A Program for solving crystal structures, Sheldrick G M 1997 University of Göttingen, Germany

31. SHELXL-97. Program for the Refinement of Crystal structures Sheldrick G M 1997 University of Göttingen, Germany 
32. Dyer D J 1989 In Application of absorption spectroscopy of organic compounds (New Delhi: Prentice-Hall) p. 37

33. Ouyang K, Hao W, Zhang W X and Xi Z 2015 Transition-Metal-Catalyzed Cleavage of C-N Single Bonds Chem. Rev. 11512045

34. Zhang H, Cui X, Yao X, Wang H, Zhang J and Wu Y 2012 Directly fused highly substituted naphthalenes via Pd-catalyzed dehydrogenative annulation of N,Ndimethylaminomethyl ferrocene using a redox process with a substrate Org. Lett. 142925
35. Aneetha $\mathrm{H}$, Zacharias $\mathrm{P} \mathrm{S}$, Srinivas B, Lee $\mathrm{G} \mathrm{H}$ and Wang Y 1998 Synthesis and characterization of Cp* $\mathrm{Rh}(\mathrm{III})$ and $\operatorname{Ir}(\mathrm{III})$ polypyridyl complexes: Fluxional behavior of $\mathrm{Rh}(\mathrm{III})$ complexes and molecular structure of $[\mathrm{Cp} * \mathrm{Rh}(\mathrm{Ph}$-terpy $) \mathrm{Cl}] \mathrm{BF}_{4}$ complex $\left(\mathrm{Cp}^{*}=\eta^{5}\right.$ $\left.\left(\mathrm{C}_{5} \mathrm{Me}_{5}\right)\right)$ Polyhedron 18299

36. Singh K S and Kaminsky W 2014 Iridium(III) and rhodium(III) triazoles by 1,3-dipolar cycloadditons to a coordinated azide in iridium(III) and rhodium(III) compounds J. Coord. Chem. 193252 